\title{
Challenges of Female Instructors and Administrative Workers to Ascribe Management Positions in Debre Markos University
}

\author{
Bizualem Lemma Ketema (MBA) \\ Debre Markos University, College of Business and Economics, Department of Management)
}

\begin{abstract}
The general objective of the study was to identify the challenges of female instructors and administrative workers to ascribe management positions in Debre Markos University. To achieve the objective of the study from 927 total populations who were working in Debre Markos University 280 sample have taken trough simple random sampling method. Primary data were collected through questionnaires from a sample of 280 respondents. Descriptive statistics were used to describe the existing situation of women's representation in leadership in Debre Markos University and describe the challenges of female instructors and administrative workers to ascribe management positions, from the descriptive result, it has shown that the representation women in leadership position is very low. Finally, it is recommended that; women should have confidence for upward advancements to managerial positions, have motivation and interests towards managerial positions, proactive towards managerial positions and are active in acquiring the necessary leadership skills, believe in their competence and ability on managerial positions. The study of this finding revealed that personal challenges seem to have major challenge as compared to societal and organizational challenges that impede women to ascribe management positions.
\end{abstract}

Keywords: Ascribe management positions, Social challenge, Organizational challenge, Personal challenge, Empowerment, Debre Markos University

DOI: $10.7176 /$ RHSS/10-5-02

Publication date:March $31^{\text {st }} 2020$

\section{Introduction}

Leadership is not a simple process which requires multiple abilities whether assumed by female or male (AlJaradat, M \& Khaled M, 2014). According to Carey (2007), female leaders are more assertive and persuasive, have a stronger need to get things done and are more willing to take risks than male leaders. Female leaders were also found to be more empathetic and flexible, as well as stronger in interpersonal skills than their male counterparts. In most societies with patriarch, females are regarded as inferior to their male counterparts (Gudata and Moges, 2016). In an ideal world, public institutions are guided by principles of fairness, accountability, justice, equality and non-discrimination, and serves as a model of governance for society which includes the promotion of gender equality and women's empowerment in the civil service workforce. However, globally; this is not yet the reality. Instead of being a driving force behind the implementation of internationally-agreed goals on gender equality and human rights standards and principles, in many developed and developing countries, public administration often remains a patriarchal institution, perpetuating gender biased traditions, attitudes and practices women do not yet participate equally in public administration, especially in leadership and decision-making (UNDP, 2014).

Akpan, E.O (2015) stated that the issue of women on management position is gaining attention globally. Empirical findings confirmed that institutions with the highest proportion of females in the board room outperform than those institutions with no female (Fondas\&Sassalos, 2000; Carter, Simkins\& Simpson, 2003; Ismail, Abdullah \& Simpson, 2003; Zelechowski\&Bilimoria, 2004; Farrel\&Hersh, 2005 and McKinsey \& Company, 2010). Terjesen, Couto \& Francisco (2016) pointed out woman has a better overview on the complex issues, attending more boards and management meetings and tend to influence larger public transparency. The United Nations development program report 2014 further stated that the target of a minimum of 30 percent of women in leadership positions, originally endorsed by the United Nations Economic and Social Council (ECOSOC) in 1990 and reaffirmed in the Beijing Platform for Action in 1995, is being approached in many public institutions and even surpassed in some. Nevertheless, while progress is being made in terms of total numbers of women in public administration, both glass ceilings and glass walls continue to present challenges to women's equal participation in decision-making positions (UNDP, 2014).

\section{Statement of the Problem/Rationale}

Ethiopia is part of all major human right treaties including the most important women's conventions, i.e. Beijing Declaration and Platform of Action (BDPA), which requires governments to attain a 30\% benchmark for women public decision making positions (Meaza, 2009). The numbers are clear-cut. Despite women's impressive gains in education and the workplace over the past 50 years, men greatly outnumber women in leadership, especially in top positions. From corporate boardrooms to the halls of Congress, from universities to the courts, from religious institutions to public organizations, men are simply much more likely than women to be leaders. Time will not solve the gender leadership gap; action will. Women's representation in leadership will not increase substantially 
without major changes in the culture, policies, and practices of the organizations where women learn and work (American Association of University women Report, 2016). Despite the government's efforts to provide equal opportunities for women and design non-discriminatory policies, the existences of deep-seated discriminatory practices thwarted their progress, yet women are economically, socially, culturally and politically disadvantaged in the enjoyment of equal rights, in accessing opportunities, decision making processes, and basic resources.

In the case of the study area, Debre Markos University, female's representation and participation in management positions is very low. According to the data from Debre Markos University Gender, HIV/AIDS and Disability affaires directorate the number of female instructors representation in the top, middle and lower management position are 1, 2 and 2 respectively; whereas the number of male instructors in top, middle and lower management position are 4, 58, and 79 respectively and female administrative staffs representation in the top, middle and lower management position are 8,2 and 0 respectively; whereas the number of male administrative workers in top, middle and lower management position are 34, 15, and 0 respectively. The data indicates 3079 workers out of these 927 female workers around 31.5\%. But when we see the management positions from the available total of 205 management positions only 15 that are only $7.3 \%$ are held by female instructors and administrative workers which is very negligible figure. According to the data management positions in the university are dominated by male. This indicates women are still limited in subordinate's positions. Despite the fact that there is progress being made in terms of total numbers of employed women, segregation of women in management positions or disparity between men and women in management positions is persistent problem that exist. Hence, this research examined the challenges that affect female instructors and administrative workers to ascribe management position in Debre Markos University.Therefore, based on the above statement; this study is able to assess the challenges of female instructors and administrative workers to ascribe management positions in Debre Markos University.

\section{Objectives}

The general objective of the study is to identify and investigate the challenges of Female Instructors and Administrative Workers to Ascribe Management Positions in Debre Markos University.

Specific objectives: Specific objectives of the study includes: to investigate the extent to which women participate in management positions in the university, to examine the perception of female instructors and administrative workers to the challenges towards ascribing management positions in Debre Markos University.

\section{Research Methodology}

To achieve the objective of this study, data was collected from both primary and secondary sources. To select sample respondents from the total study population probability sampling methods-simple random sampling method were employed. From 927 total populations (female academic and administrative staff) who were working in Debre Markos University 280 sample has taken trough simple random sampling method. After determine the sample size Slovin's sampling formula, the relevant data were collected through structured questionnaires. To achieve the objective of this research, descriptive statistics were used to describe the existing situation of women's representation in leadership in Debre Markos University and describe the challenges of female instructors and administrative workers to ascribe management positions in the form of tables, frequencies, percentages and modes.

\section{Results and Discussions}

\subsection{The Extent of Women Participation in Management position} Table 1: Extent of Women Participation in Management position

\begin{tabular}{|l|l|c|c|c|c|c|c|}
\hline No. & Questions SDA & DA & N & A & SA & M \\
\hline 1 & $\begin{array}{l}\text { Women are sufficiently } \\
\text { represented in leadership } \\
\text { position. }\end{array}$ & $11.1 \%(17)$ & $34.6 \%(53)$ & $1.3 \%(2)$ & $52.3 \%(80)$ & $.7 \%(1)$ & A \\
\hline 2 & $\begin{array}{l}\text { Women are posted/ } \\
\text { represented uniformly across } \\
\text { leadership position. }\end{array}$ & $23.53 \%(36)$ & $69.93 \%(107)$ & $2.6 \%(4)$ & $3.3 \%(5)$ & $.7 \%(1)$ & DA \\
\hline 3 & $\begin{array}{l}\text { Women leaders are active } \\
\text { and exemplary model in } \\
\text { making decisions. }\end{array}$ & & $71.9 \%(110)$ & $3.3 \%(5)$ & $7.2 \%(11)$ & $1.3 \%(2)$ & DA \\
\hline 4 & $\begin{array}{l}\text { Women at different } \\
\text { leadership positions are } \\
\text { confident in decisions. }\end{array}$ & $3.9 \%(6)$ & $11.1 \%(17)$ & $2 \%(3)$ & $71.2 \%(109)$ & $11.8 \%(18)$ & A \\
\hline
\end{tabular}

Source: Worked Out by the Researchers from 2019 Survey Data

NB.SDA-Strongly Disagree, DA-Disagree, N- Neutral, A-Agree, SA-Strongly Agree, M- Mode

As presented in table 1 , about participation of women in management positions. Regarding women are 
sufficiently represented in leadership position $52.3 \%(80)$ of the respondents agreed, $34.6 \%(53)$ disagreed, $11.1 \%(17)$ strongly disagreed. The mode is agree (80). Concerning uniformly representation of women across leadership position $71.9 \%$ ( 110) of the respondents disagreed and $21.6 \%(33)$ strongly disagreed. The mode is disagree (110). However, few 3.3\% agreed, $0.7 \%$ strongly agreed, and $2.6 \%$ remained neutral.

Respondents degree of agreement with the idea that women leaders are active and exemplary model in making decisions $71.9 \%$ ( 110) disagreed, $16.3 \%$ (25) strongly disagreed, $7.2 \%$ ( 11) agreed and 1.3\%(2) strongly agreed. The mode is disagree (110).

As regard the issue that women at different leadership positions are confident in decisions, $71.2 \%(109)$ of the respondents agreed, $11.8 \%$ ( 18) strongly agreed, $11.1 \%(17)$ disagreed. The mode is agree (109).

Women participation in leadership position analysis indicate that more than half of the respondents $(52.3 \%)$ said women are sufficiently represented in leadership position, but with regard to uniform representation of women across leadership position majority of the respondents $(71.9 \%)$ disagreed with the idea. This indicates that women are participated in lower level position. Majority of the respondents $(71.2 \%)$ agreed with the statement that women at different leadership positions are confident in decisions.

Women participation in management positions indicates, even though women are sufficiently represented in leadership position and women at different leadership positions are confident in decisions; women are not represented uniformly across leadership position and they are not active and exemplary model in making decisions.

5.2. The perception of women to the challenges that impede women towards ascribing management positions Research conducted by Birikti (2015) on an assessment of factors Affecting Participation of women in Management Position: the Case of ethio telecom Company. The objective of the study was to assess and examine the factors that affect women's to hold managerial positions and also identify possible strategies that can be used to enhance women's participation in senior management places in the context of ethio telecom Company. In his finding indicated that women are highly underrepresented in higher level positions due to some factors such as educational gap, socio cultural attitude; organizational culture and company recruitment and promotion practice are the major ones. Due to this women's are unable to get role model and less confidence for the position.

Similarly research conducted by Hirut (2014) on factors affecting women's participation in secondary school leadership in selected sub-cities of Addis Ababa. The main objective of the study was to identify the main factors that prevent women to accept educational leadership at different educational administration levels, particularly in secondary schools of Addis Ababa. According to the study finding the socialization of girls and boys moderately influences women's involvement in school leadership. Further, the study indicated that majority of the respondents believe that there is a change of attitude on women's ability and skill. Patriarchal ideology of the society and coworkers also moderately affected women participation in school leadership.

Regarding women's attitude towards themselves is a moderate cause for their participation in school leadership. Feeling as they are confined at lower level tasks under men, considering themselves as they are less accepted than men, and exhibiting poor risk taking of themselves affects them moderately. But comparing with the other points what affects them more is acknowledging the world as masculine. Institutional factors are moderate causes for women's participation in school leadership. Further women's home and family responsibility is a major cause to their participation in school leadership. Still the burden of home and family chores are on the shoulder of women, among the points the only having minimal authority in controlling, commanding and managing of household than their counterparts is moderate cause for the participation of women in principal ship was the main finding of the study.

Table 2: The Perception of Women on Organizational Challenges

\begin{tabular}{|l|l|c|c|c|c|c|c|}
\hline No. & Questions & SDA & DA & N & A & SA & M \\
\hline 1 & $\begin{array}{l}\text { The University's culture support } \\
\text { women's advancement towards } \\
\text { managerial positions. }\end{array}$ & $9.8 \%(15)$ & $25.5 \%(39)$ & $1.96 \%(3)$ & $59.5 \%(91)$ & $2.6 \%(4)$ & A \\
\hline 2 & $\begin{array}{l}\text { Women have active participation } \\
\text { in university. }\end{array}$ & $5.2 \%(8)$ & $73.2 \%(112)$ & $5.9 \%(9)$ & $14.4 \%(22)$ & $1.3 \%(2)$ & DA \\
\hline 3 & $\begin{array}{l}\text { The university leaders } \\
\text { recruitment practices encourage } \\
\text { women participation. }\end{array}$ & $7.8 \%(12)$ & $24.2 \%(37)$ & $3.9 \%(6)$ & $60.8 \%(93)$ & $3.3 \%(5)$ & A \\
\hline 4 & $\begin{array}{l}\text { There are more active and } \\
\text { exemplary model women in the } \\
\text { university management positions. }\end{array}$ & $5.2 \%(8)$ & $22.9 \%(35)$ & $51.6 \%(79)$ & $15.7 \%(24)$ & $1.3 \%(2)$ & N \\
\hline
\end{tabular}




\begin{tabular}{|l|l|c|c|c|c|c|c|}
\hline No. & Questions & SDA & DA & N & A & SA & M \\
\hline 5 & $\begin{array}{l}\text { There is attractive work } \\
\text { environment in university that } \\
\text { encourages women to aspire } \\
\text { managerial positions. }\end{array}$ & $8.5 \%(13)$ & $72.5 \%(111)$ & $5.9 \%(9)$ & $11.8 \%(18)$ & $1.3 \%(2)$ & DA \\
\hline 6 & $\begin{array}{l}\text { The university leaders are } \\
\text { committed to improve women } \\
\text { participation in managerial } \\
\text { positions. }\end{array}$ & & & & & & \\
\hline
\end{tabular}

Source: Worked Out by the Researchers from 2019 Survey Data

NB.SDA-Strongly Disagree, DA-Disagree, N- Neutral, A-Agree, SA-Strongly Agree, M- Mode

As presented in table 2, perception of women on university's culture in support women's advancement towards managerial positions $59.5 \%$ (91) of the respondents agreed and $25.49 \%$ (39) of the respondents were disagreed. The mode is agree (91). With regard to active participation of women in the university $73.2 \%(112)$ of the respondents disagree and $14.4 \%(22)$ were agreed. The mode is disagreed (112).

Concerning university's leaders recruitment practices encourage women participation60.8 \%( 93) of the respondents were agreed and 24.2(37) of the respondents were disagreed. The mode is agree (93). Regarding the presence of more active and exemplary model women in the university management positions51.6\%( 79) of the respondents neutral, $22.9 \%$ (35) disagreed, and $15.7 \%(24)$ agreed. And the mode is neutral (79).About the presence of attractive work environment in the university that encourages women to aspire managerial positions $72.5 \%(111)$ of the respondents were disagree, $11.8 \%(18)$ agreed, and the mode is disagree (111). Regarding commitment of university leaders to improve women participation in managerial positions $59.5 \%(91)$ of the respondents were agree, $23.5 \%$ (36) disagreed, $6.5 \%(10)$ of the respondents strongly disagree and the mode is agree (91).

Organizational challenges analysis indicates, even though the university's culture supports women's advancement towards managerial positions, university's leadership recruitment practices encourage women participation, better commitment of university leaders to improve women participation in managerial positions; the work environment in the university is not such attractive that encourages women to aspire managerial positions and there is no active participation of women in the university.

Table 3: The Perception of women on Social Challenges

\begin{tabular}{|c|c|c|c|c|c|c|c|}
\hline No. & Questions & SDA & DA & $\mathbf{N}$ & $\mathbf{A}$ & SA & M \\
\hline 1 & $\begin{array}{l}\text { Women are expected to have } \\
\text { leadership role in the } \\
\text { society. }\end{array}$ & $56.2 \%(86)$ & $16.3 \%(25)$ & $5.9 \%(9)$ & $16.3 \%(25)$ & $5.2 \%(8)$ & DA \\
\hline 2 & $\begin{array}{l}\text { Work is performed better if } \\
\text { women lead. }\end{array}$ & $2 \%(3)$ & $4.6 \%(7)$ & $1.3 \%(2)$ & $66 \%(101)$ & $26.1 \%(40)$ & A \\
\hline 3 & $\begin{array}{l}\text { Women are culturally } \\
\text { encouraged to be leader. }\end{array}$ & $7.2 \%(11)$ & $73.9 \%(113)$ & $4.6 \%(7)$ & $12.4 \%(19)$ & $2 \%(3)$ & DA \\
\hline 4 & $\begin{array}{l}\text { Our religions support to } \\
\text { empower women for } \\
\text { leadership position. }\end{array}$ & $6.53 \%(10)$ & $21.57 \%(33)$ & $50.3 \%(77)$ & $16.3 \%(25)$ & $5.2 \%(8)$ & $\mathrm{N}$ \\
\hline 5 & $\begin{array}{lrr}\text { The society } & \text { believe in } \\
\text { Women } & \text { can } & \text { lead } \\
\text { challenging } & & \text { working } \\
\text { environment. } & & \end{array}$ & $54.9 \%(84)$ & $23.5 \%(36)$ & $2.6 \%(4)$ & $12.4 \%(19)$ & $6.5 \%(10)$ & SDA \\
\hline 6 & $\begin{array}{l}\text { Women are socially and } \\
\text { culturally suffering from } \\
\text { work stereotype and } \\
\text { discrimination because of } \\
\text { gender perception. }\end{array}$ & $8.5 \%(13)$ & $19 \%(29)$ & $3.9 \%(6)$ & $62.7 \%(96)$ & $5.9 \%(9)$ & A \\
\hline
\end{tabular}

Source: Worked Out by the Researchers from 2019 Survey Data

NB.SDA-Strongly Disagree, DA-Disagree, N- Neutral, A-Agree, SA-Strongly Agree, M- Mode

As indicated in table 3, respondents response concerning women are expected to have leadership role in the society $56.2 \%(86)$ of the respondents strongly disagreed and $16.3 \%(25)$ of the respondents were disagreed and $16.3 \%(25)$ agree. The mode is strongly disagree (86). Respondents degree of agreement on the idea that work is performed better if women lead $66 \%$ (101) of the respondents agree and $26.1 \%(40)$ were strongly agreed. The mode is agreed (101). Few 4.6\% disagreed, $2 \%$ strongly disagreed, and $1.3 \%$ remained neutral. 
Concerning women are culturally encouraged to be leader $73.9 \%(113)$ of the respondents were disagree with the idea and $12.4 \%$ ( 19) of the respondents were agreed. The mode is agree (93). However, few $7.2 \%$ disagreed, $4.6 \%$ neutral, and $2 \%$ strongly agree. Regarding the society believe in women can lead challenging work environment $54.9 \%(84)$ of the respondents were strongly disagree, $23.5 \%(36)$ disagreed, $12.4 \%(19)$ agreed, $6.5 \%$ ( 10) strongly agreed, $2.6 \%$ (4) remained neutral. And the mode is strongly disagree (84).Respondents degree of agreement with the idea that women are socially and culturally suffering from work stereotype and discrimination because of gender perception $62.7 \%(96)$ of the respondents agreed, 19\%( 29) disagreed, $8.5 \%$ ( 13) strongly disagreed, $5.9 \%$ (9) strongly agreed, $3.9 \%(6)$ remained neutral. And the mode is agreed (96).

Observing social challenges even though work is performed better if women lead, women are not expected to have leadership role by the society, culturally not encouraged to be leader, doubtful assumption in the society that women can't lead challenging working environment and women are socially and culturally suffering from work stereotype and discrimination because of gender perception.

Table 4: The Perception of women on Personal Challenges

\begin{tabular}{|c|c|c|c|c|c|c|c|}
\hline No. & Questions & SDA & DA & $\mathbf{N}$ & $\mathbf{A}$ & SA & $\mathbf{M}$ \\
\hline 1 & $\begin{array}{l}\text { Women have confidence } \\
\text { on their own for upward } \\
\text { advancements to } \\
\text { managerial positions. }\end{array}$ & $2.6 \%(4)$ & $58.8 \%(90)$ & $5.2 \%(8)$ & $27.5 \%(42)$ & $5.9 \%(9)$ & DA \\
\hline 2 & $\begin{array}{l}\text { Women have motivation } \\
\text { and interests towards } \\
\text { managerial positions. }\end{array}$ & $1.3 \%(2)$ & $62.7 \%(96)$ & $4.6 \%(7)$ & $24.2 \%(37)$ & $7.2 \%(11)$ & DA \\
\hline 3 & $\begin{array}{l}\text { Women are ready to accept } \\
\text { responsibility of } \\
\text { management positions. }\end{array}$ & $1.3 \%(2)$ & $15 \%(23)$ & $3.3 \%(5)$ & $72.5 \%(111)$ & $7.8 \%(12)$ & A \\
\hline 4 & $\begin{array}{l}\text { Women are } \begin{array}{l}\text { proactive } \\
\text { towards } \\
\text { positions. }\end{array} \\
\text { managerial } \\
\end{array}$ & $1.3 \%(2)$ & $65.4 \%(100)$ & $7.2 \%(11)$ & $20.9 \%(32)$ & $5.2 \%(8)$ & DA \\
\hline 5 & $\begin{array}{l}\text { Women are competent } \\
\text { enough to acquire the } \\
\text { necessary leadership skills. }\end{array}$ & $50.3 \%(77)$ & $11.8 \%(18)$ & $3.3 \%(5)$ & $24.2 \%(37)$ & $10.5 \%(16)$ & SDA \\
\hline 6 & $\begin{array}{l}\text { Women believe in their } \\
\text { competence and ability on } \\
\text { managerial positions. }\end{array}$ & $.7 \%(1)$ & $63.4 \%(97)$ & $2 \%(3)$ & $26.1 \%(40)$ & $7.8 \%(12)$ & DA \\
\hline 7 & $\begin{array}{l}\text { Women believe in their } \\
\text { adequate job knowledge } \\
\text { (capability) to managerial } \\
\text { positions }\end{array}$ & $1.96 \%(3)$ & $60.78 \%(93)$ & $6.53 \%(10)$ & $28.8 \%(44)$ & $4.6 \%(7)$ & DA \\
\hline
\end{tabular}

Source: Worked Out by the Researchers from 2019 Survey Data

NB.SDA-Strongly Disagree, DA-Disagree, N- Neutral, A-Agree, SA-Strongly Agree, M- Mode

As shown in Table 4, respondents were asked to indicate their degree of agreement with the idea that, women have confidence on their own for upward advancements to managerial positions, women have motivation and interests towards managerial positions, women are ready to accept responsibility of management position in the university, women are proactive towards managerial positions, women are competent enough to acquire the necessary leadership skills, women believe in their competence and ability on managerial positions, women believe in their adequate job knowledge (capability) to managerial positions, the respondents revealed the following opinions;

Concerning women women's confidence on their own for upward advancements to managerial positions $58.8 \%(90)$ of the respondents disagreed and $27.5 \%(42)$ of the respondents were agree. The mode is strongly disagree (90). Regarding women's motivation and interests towards managerial positions $62.7 \%(101)$ of the respondents disagreed and $24.2 \%$ ( 37 ) were agreed. The mode is disagreed (96). Few $1.3 \%$ strongly disagreed, $7.2 \%$ strongly agreed, and $1.3 \%$ remained neutral.

Concerning women's readiness to accept responsibility of management positions $72.5 \%(111)$ of the respondents agreed with the idea and $15 \%(23)$ of the respondents disagreed. The mode is agree (111).

With regard to the idea that women are proactive towards managerial positions $65.4 \%(100)$ of the respondents disagreed and $20.9 \%$ ( 32) agreed. And the mode is disagreed (100).

Concerning the idea women are competent enough to acquire the necessary leadership skills $50.3 \%(77)$ of the respondents were strongly disagree, $24.2 \%$ (37) agreed, $11.8 \%$ (18) of the respondents disagreed, $10.5 \%(16)$ strongly agreed and few $3.3 \%$ ( 5) of the respondents had no opinion/neutral in this regard. And the mode is 
strongly disagreed (77).

As regard the issue that women believe in their competence and ability on managerial positions $63.4 \%(97)$ of the respondents disagreed and $26.1 \%(40)$ agreed. And the mode is disagree (97).Respondents degree of agreement with the idea that womenbelieve in their adequate job knowledge (capability) to managerial positions $60.1 \%(92)$ of the respondents disagreed and $28.8 \%(44)$ agreed. And the mode is disagreed (92).

Results concerning personal challenges shows, even though women are ready to accept responsibility of management positions, they are doubtful in their confidence for upward advancements to managerial positions, have no better motivation and interests towards managerial positions, lacks preparation towards managerial positions and are not active in acquiring the necessary leadership skills, unable to believe in their competence and ability on managerial positions.

Table 5: The Perception of women on Empowerment

\begin{tabular}{|l|l|c|c|c|c|c|c|}
\hline No. & Questions & SDA & DA & N & A & SA & M \\
\hline 1 & $\begin{array}{l}\text { Women in our university have } \\
\text { access to relevant training on } \\
\text { leadership. }\end{array}$ & $13.7 \%(21)$ & $74.5 \%(114)$ & $3.9 \%(6)$ & $7.2 \%(11)$ & $.7 \%(1)$ & DA \\
\hline 2 & $\begin{array}{l}\text { The University has consistent } \\
\text { plan to empower women as } \\
\text { leaders. }\end{array}$ & $7.8 \%(12)$ & $69.3 \%(106)$ & $12.4 \%(19)$ & $9.8 \%(15)$ & $.7 \%(1)$ & DA \\
\hline 3 & $\begin{array}{l}\text { The University set sustainable } \\
\text { motivation system for women } \\
\text { empowerment. }\end{array}$ & $15.7 \%(24)$ & $23.5 \%(36)$ & $3.3 \%(5)$ & $56.2 \%(86)$ & $1.3 \%(2)$ & $\mathrm{A}$ \\
\hline 4 & $\begin{array}{l}\text { The University leaders are } \\
\text { committed to encourage } \\
\text { women's overall development } \\
\text { in leadership. }\end{array}$ & $7.8 \%(12)$ & $20.9 \%(32)$ & $55.6 \%(85)$ & $13.1 \%(20)$ & $2.6 \%(4)$ & N \\
\hline 5 & $\begin{array}{l}\text { The University encourages and } \\
\text { values the women employees } \\
\text { creativity and contributions in } \\
\text { leadership position. }\end{array}$ & $10.5 \%(16)$ & $21.6 \%(33)$ & $3.9 \%(6)$ & $60.1 \%(92)$ & $3.9 \%(6)$ & $\mathrm{A}$ \\
\hline
\end{tabular}

Source: Worked Out by the Researchers from 2019 Survey Data

NB.SDA-Strongly Disagree, DA-Disagree, N- Neutral, A-Agree, SA-Strongly Agree, M- Mode

As indicated in table 5, about emphasis given in empowering women. Regarding the idea that women have access to relevant training on leadership $74.5 \%(114)$ of the respondents disagreed, $13.7 \%(21)$ agreed. However, few $7.2 \%$ agreed, $0.7 \%$ strongly agreed, and $3.9 \%$ remained neutral. The mode is disagree (114). Concerning presence of consistent plan to empower women as leaders $69.3 \%$ ( 106) of the respondents disagreed, $9.8 \%(15)$ agreed and $12.4 \%(19)$ had no opinion about the statement. The mode is disagree (106).

Regarding motivation system for women empowerment in the university $56.2 \%(86)$ of the respondents agreed with the idea, $23.5 \%$ (36) disagreed, $15.7 \%$ (24) strongly disagreed. The mode is agree (86). As regard the issue that university's leader commitment to encourage women's overall development in leadership more than half of the respondents $55.6 \%$ ( 85) of the respondents had no opinion about the statement, $20.9 \%(32)$ disagreed, $13.1 \%(20)$ agreed. And the mode is neutral (85).Respondents degree of agreement with the idea that university encourages and values the women employees' creativity and contributions in leadership position $60.1 \%(92)$ of the respondents agreed, $21.6 \%(44)$ disagreed and $10.5 \%$ (16) strongly disagreed. And the mode is agreed (92). Empowerment analysis indicate that there is moderate sustainable motivation system for women empowerment and the university encourages and values the women employees' creativity and contributions in leadership position. But have no access to relevant training on leadership and there is lack of consistent plan to empower women.

\section{Conclusions and Recommendations}

\subsection{Conclusions}

The result of this study shows that: results regarding organizational challenges indicates; even though the university's culture supports women's advancement towards managerial positions, university's leadership recruitment practices encourage women participation, better commitment of university leaders to improve women participation in managerial positions; the work environment in the university is not such attractive that encourages women to aspire managerial positions and there is no active participation of women in the university.

Concerning social challenges even though work is performed better if women lead, women are not expected to have leadership role by the society, culturally not encouraged to be leader, doubtful assumption in the society that women can't lead challenging working environment and women are socially and culturally suffering from work stereotype and discrimination because of gender perception.

Results related to personal challenges indicates even though women are ready to accept responsibility of 
management positions, they are doubtful in their confidence for upward advancements to managerial positions, have no better motivation and interests towards managerial positions, lacks preparation towards managerial positions and are not active in acquiring the necessary leadership skills, unable to believe in their competence and ability on managerial positions.

Empowerment analysis indicate that there is moderate sustainable motivation system for women empowerment and the university encourages and values the women employees' creativity and contributions in leadership position. But have no access to relevant training on leadership and there is lack of consistent plan to empower women.

Perception of women on the degree of participation in management position the result indicates that even though women are sufficiently represented in leadership positions and they are confident in making decisions, they are not uniformly represented across leadership position and they are not active and exemplary model in making decisions.

Regarding the perception differences between female instructors and female administrative workers as to the possible challenges to ascribe management positions, the result indicates that there is no statistically significant difference in the perception scores of female academic and female administrative staffs on the organizational, social and personal factors these implies all the organizational, social and personal factors discussed so far affects equally female academic and female administrative staffs.

\subsection{Recommendations}

Based on the result of the study and the conclusion above the following recommendations have been forwarded:

- To create motivation for women in ascribing management positions, in additions to better commitment of university leaders to improve women participation in managerial positions; it is important to create work environment that is suitable for women to aspire managerial positions and men who are in management positions should give positive attitude to women.

- There is contradict perception that in one side work is performed better if women lead; on the other side women are not expected to have lead ership role by the society, culturally not encouraged to be leader, doubtful assumption in the society that women can't lead challenging working environment and women are socially and culturally suffering from work stereotype and discrimination because of gender perception. In order to improve women participation in managerial position, the university community should believe in that women can be leaders/ managers and be efficient and effective.

- Women themselves beyond readiness to accept responsibility of management positions, they should have confidence for upward advancements to managerial positions, have motivation and interests towards managerial positions, proactive towards managerial positions and are active in acquiring the necessary leadership skills, believe in their competence and ability on managerial positions. And women who are in management position should be active and exemplary model for others to ascribe management positions.

\section{References}

1. (AAUW), T. A. (2016). Barriers and Bias the status of women in leadership. Washington: AAUW 1111 Sixteenth ST.N.W Washington,DC20036 United States of America.

2. Akpan, E. O. (2015). Corporate Board Meetings And Company Performance: Empirical Evidence from Nigerian Quoted Companies. Global Journal of Commerce \& Management Perspective G.J.C.M.P., Vol.4 (1):75-82.

3. Al-Jaradat, M. and Khaled M. (2014). Challenges Facing Women Academic Leadership in Secondary Schools of Irbid Educational Area. International Education Studies; Vol. 7, No. 5; 2014 ISSN 1913-9020 E-ISSN 1913-9039, Canadian Center of Science and Education.

4. Carey, W. P. (2007). They're Few and Far Between, but Female Executives Benefit the Firms They Work For.

5. Carter, D. A., D'Souza, F., Simkins, B. J., \& Simpson, W. G. (2010). The gender and ethnic diversity of US boards and board committees and firm financial performance. Corporate Governance: An International Review, 18(5), 396-414.

6. Farrell, K. A., \&Hersch, P. L. (2005). Additions to corporate boards: the effect of gender. Journal of Corporate finance, 11(1), 85-106.

7. Fondas, N., and Sassalos,V.(2000). "A Different Voice in the Boardroom: How the Presence of Women Directors Affects Board. Influence over Management," Global Focus, 12: 13-22.

8. GudataAbaraChaliand MogesNegeroErana. (2016). An Assessment of Women Empowerment in Public Institutions:The Case of BenishangulGumuz Regional Bureaus

9. Ismail, K., Abdullah, S. N., \&Nachum, L. (2013, April). Women on Boards of Directors of Malaysia Firms: Impact on Market and Accounting Performance. In Academy of Management Proceedings (Vol. 1, No. 1, pp. aomafr-2012). Academy of Management.

10. McKinsey \& Company. (2010). Women matter 2010, women at the top of corporations: making it happen. 
11. Meaza Ashenafi (2009). Factors Affecting Women Participation in Politics and Decision making. Master of Arts Thesis.

12. Terjesen, S., Couto, E. B., \& Francisco, P. M. (2016). Does the presence of independent and female directors impact firm performance? A multi-country study of board diversity. Journal of Management \& Governance, 20(3), 447-483.

13. UNDP. (2014). Gender equality in public sector. New york: UNDP.

14. Zelechowski, D. D., \&Bilimoria, D. (2004). Characteristics of women and men corporate inside directors in the US. Corporate governance: an international review, 12(3), 337-342. 